\title{
SEGMENTASI DAN STRATEGI PEMASARAN KOPI JAVA IJEN RAUNG BONDOWOSO
}

\section{SEGMENTATION AND MARKETING STRATEGY OF JAVA IJEN RAUNG BONDOWOSO COFFEE}

\author{
Weni Indah Doktri \\ Universitas Bondowoso \\ Email: wennyhariyadi@gmail.com
}

\begin{abstract}
ABSTRAK
Kabupaten Bondowoso merpakan kabupaten penghasil kopi arabika terbaik di Indonesia, yang dikenal dengan Kopi Java Ijen Raung, akan tetapi kopi yang dikonsumsi bukan Kopi Java Ijen Raung melainkan kopi olahan pabrik lainnya. Fenomena ini tentunya mengharuskan agroindustri kopi Java Ijen Raung mengembangkan produk kopinya agar dapat lebih diterima oleh konsumen kopi di Bondowoso. Suatu informasi mengenai perilaku konsumen sangat dibutuhkan dengan melakukan segmentasi, menganalisa karakteristik konsumen kopi, sehingga mempermudah Kopi Java Ijen Raung dalam menentukan strategi pemasarannya. Hasil penelitian menunjukkan bahwa konsumen kopi terbanyak adalah laki-laki, remaja akhir, menengah ke bawah yang memiliki pekerjaan wiraswasta, berpendidikan SMA, menikah dan tinggal lebih dari $5 \mathrm{Km}$ dari kota. Konsumen kopi di Kabupaten Bondowoso lebih banyak yang memilih Top Coffee di banding kopi olahan yang lain. Konsumen kopi Bondowoso banyak yang merupakan penggemar kopi dengan status loyal terhadap merek.
\end{abstract}

Kata Kunci : segmentasi, preferensi, faktor dan strategi pemasaran.

\begin{abstract}
Bondowoso Regency is the best Arabica coffee producing district in Indonesia, known as Kopi Java Ijen Raung, but the coffee consumed is not Kopi Java Ijen Raung but other processed coffee. This phenomenon certainly requires the Java coffee agroindustry Ijen Raung to develop coffee products to be more acceptable to coffee consumers in Bondowoso. An information about consumer behavior is needed by segmenting, analyzing the characteristics and preferences of consumers towards processed coffee products as well as factors that influence coffee buying decisions, making it easier for Coffee Java Ijen Raung in determining its marketing strategy. The results showed that the most coffee consumers were late adolescents, middle to lower who had self-employed jobs, had high school education, were married and lived more than $5 \mathrm{Km}$ from the city. Bondowoso coffee consumer preferences show that most coffee consumers prefer Top Coffee than other processed coffee. Many Bondowoso coffee consumers are coffee fans with loyal and loyal status towards the brand.
\end{abstract}

Keywords: segmentation, preferences, factors and marketing strategies. 


\section{PENDAHULUAN}

Kabupaten Bondowoso merupakan salah satu kabupaten di Provinsi Jawa Timur dengan jumlah konsumsi kopi yang tergolong tinggi. Kopi merupakan bagian dari aktivitas masyarakat di Bondowoso. Hampir di setiap aktivitas masyarakat di Bondowoso selalu mengkonsumsi kopi. Peluang ini dimanfaatkan dengan membuat produk kopi dengan memiliki nilai tambah yang lebih baik dibandingkan dengan kopi yang ada di pasaran, baik itu dari segi kualitas maupun kuantitas, seperti Kopi Java Ijen Raung, karena Kabupaten Bondowoso adalah salah satu penghasil kopi arabika terbaik di Indonesia, akan tetapi kopi yang dikonsumsi masyarakat di Bondowoso ternyata bukanlah kopi Java Ijen Raung, melainkan kopi buatan pabrik umumnya. Fenomena ini tentunya mengharuskan agroindustri kopi Java Ijen Raung mengembangkan produk kopinya agar dapat lebih diterima oleh konsumen kopi di Bondowoso. Keadaan ini tidak cukup dengan sekedar mendeklarasikan Kabupaten Bondowoso sebagai Republik Kopi, namun dibutuhkan suatu informasi mengenai perilaku konsumen dengan melakukan segmentasi yang menganalisa karakteristik konsumen dan memenangkan persaingan bisnis kopi khususnya di wilayah Bondowoso sendiri.

Kopi Java Ijen Raung tidak begitu terkenal di kalangan masyarakat Bondowoso khususnya konsumen kopi. Fenomena tersebut menyebabkan perlu adanya penelitian yang mampu menggambarkan kondisi perilaku konsumen kopi di Bondowoso dengan melakukan segmentasi, agar dapat dijadikan sebagai landasan untuk menyusun strategi pemasaran kopi Java Ijen Raung di Bondowoso. Permasalahan di atas dapat menjadi dasar perumusan masalah dalam penelitian ini, antara lain :

1. Bagaimanakah segmentasi perilaku konsumen kopi di Bondowoso?

2. Bagaimanakah implikasi permasalahan tersebut terhadap strategi pemasaran?

Penelitian ini bertujuan untuk :

1. Mengetahui pengelompokan dan karakteristik perilaku konsumen kopi di Bondowoso berdasarkan aspek demografis dan geografis.

2. Mengetahui strategi pemasaran yang akan dilakukan berdasarkan pengelompokan dan karakteristik konsumen kopi di Bondowoso.

Pedekatan yang digunakan untuk menjawab masalah penelitian ini adalah dengan menggunakan metode deskriptif, analitik dan korelasional. Konsep penelitian ini mengelompokkan dan memetakan konsumen kopi berdasarkan karakteristiknya. 


\section{TINJAUAN PUSTAKA}

\section{Segmentasi Pasar}

Segmentasi adalah seni untuk mengidentifikasi dan menggambarkan dengan tepat kesempatan yang berkembang di pasar (Dimyati, 2012:89). Pada saat yang sama segmentasi adalah ilmu untuk memandang pasar berdasarkan variabel geografi, demografi, psikografi dan perilaku atau bahkan segmen dari variabel-variabel tersebut. Menurut Kertajaya dalam Dimyati (2012:89) segmentasi adalah cara memandang suatu pasar secara kreatif. Segmentasi adalah tentang suatu pemetaan suatu pasar menjadi beberapa kategori dengan mengumpulkan perilaku yang serupa dari pelanggan ke dalam sebuah segmen. Segmentasi adalah strategi pemetaan dari perusahaan. Segmentasi pasar didefinisikan sebagai proses membagi sebuah pasar menjadi kelompok-kelompok konsumen yang mirip kemudian menyeleksi kelompok-kelompok dan individu yang paling sesuai untuk dilayani perusahaan tersebut (Peter dan Olson, 2014:161).

Kotler dan Amstrong dalam Dimyati (2014:95-97) mengklasifikasikan jenis-jenis segmentasi sebagai berikut :

1. Segmentasi geografi, yaitu membagi pasar menjadi unit-ubit geografi yang berbeda, seperti Negara, propinsi, kabupaten, kota, wilayah, daerah atau kawasan. Pemasaran ini bermanfaat bagi pemasar yaitu pemasar memperoleh kepastian keana atau dimana produk iini akan dipasarkan.

2. Segmentasi demografi. Yaitu memberikan gambaran bagi pemasar kepada siapa produk ini harus ditawarkan. Jawaban atas pertanyaan kepada siapa dapat berkonotasi pada umu, jenis kelamin, jumlah anggota keluarga, siklus kehidupan keluarga seperti anak-anak, remaja, dewasa kawin/belum kawin keluarga muda dengan satu anak, keluarga dengan dua anak-anak, keluarga yang anaknya bekerja dan seterusya. Segmentasi demografi dapat pula berkonotasi tigkat penghasilan, pendidikan, jenis pekerjaaan, pengalaman, agama dan keturunan misalnya: Jawa, Madura, Bali, Manado, Cina dan sebagainya.

3. Segmentasi psikografi, yaitu pembeli dibagi menjadi kelompok-kelompok berdasarkan :

a. Status sosial, misalnya: pemimpin masyarakat, pendidik, golongan elite, gollongan menengah, golongan rendah; 
b. Gaya hidup, misalnya: modern, tradisional, kuno, boros, hemat, mewah dan sebagainya.

c. Kepribadian, misalnya: penggemar, pecandu atau pemerhati suatu produk.

4. Segmentasi tingkah laku, yaitu mengelompokkan konsumen berdasarkan pengetahuan, sikap, penggunaan atau reaksi terhadap suatu produk. Banyak pemasar yakin bahwa vriabel tingkah laku merupakan awal paling baik untuk membentuk segmen pasar. Segmentasi perilaku juga dapat dikelompokkan melalui indikatorindikator :

a. Manfaat yang dicari

Salah satu bentuk segmentasi yang ampuh adalah mengelompokkan pmbeli meurut manfaat berbeda yang mereka cari dari produk. Segmentasi manfaat menuntut ditemukannya manfaat utama yang dicari konsumen. Perusahaan dapat menggunakan segmentasi manfaat untuk memperjelas segmen manfaat yang mereka inginkan, karakteristiknya dan merek utama yang bersaing. Perusahaan juga dapat mencari manfaat baru dan meluncurkan merek yang meberikan manfaat tersebut.

b. Status pengguna

Pasar dapat disegentaikan menjadi kelompok bukan pengguna, mantan pengguna, pengguna potenia, pengguna pertama kali dan pengguna regular dari suatu produk. Pengguna potensial dan pengguna regular mungkin memerlukan imbauan peasaran yang berbeda.

c. Tingkat pemakaian

Pasar juga disegmentasikan menjadi kelompok pegguna ringan, menengah dan berat. Jumlah pengguna berat seringkali hanya prosentase kecil ari seluruh pasar, tetapi enghasilkan yang tinggi dari total pembelian. Pengguna produk dibgi menjadi dua, yakni pengguna ringan dan pengguna berat menurut tingkat pembelian dari produk yang spesifik.

d. Status loyalitas

Pasar dapat juga disegmentasikan berdasarkan loyalitas konsumen. Konsumen dapat loyal terhadap merek, toko dan perusahaan. Beberapa kosumen dapat benar-benar loyal, mereka selalu membeli satu macam merek. Kelompok lain agak loyal, mereka loyal pada dua merek atau lebih dari satu mereka menyukai satu merek tetapi kadangkadang membeli merek lain. Pembeli lain tidak menunjukkan 


\section{Perilaku Konsumen}

Perilaku konsumen adalah semua kegiatan, tindakan, serta proses psikologi yang mendorong tindakan tersebut pada saat membeli, ketika membeli, menggunakan, menghabiskan produk dan jasa setelah melakukan hal-hal di atas atau kegiatan mengevaluasi (Griffin dalam Sangadji dan Sopiah, 2013:8). Perilaku konsumen merujuk kepada perilaku yang diperlihatkan oleh konsumen untuk mencari, membeli, menggunakan, mengevaluasi dan menghabiskan produk barang dan jasa yang mereka harapkan akan memuaskan kebutuhan mereka (Schiffman dan Kanuk dalam Nitisusastro, 2013:32).

\section{Strategi Pemasaran}

Tull dan Kahle dalam Tjiptono (2008:6) mendefinisikan strategi pemasaran sebagai alat fundamental yang direncanakan untuk mencapai tujuan perusahaan dengan mengembangkan keunggulan bersaing yang berkesinambungan melalui pasar yang dimasuki dan program pemasaran yang digunakan untuk melayani pasar sasaran tersebut. Strategi pemasaran terdiri atas lima elemen, menurut Corey (dalam Tjiptono, 2008:6) yakni, pemilihan pasar, perencanaan produk, penetapan harga, sistem distribusi dan komunikasi pemasaran. Pemilihan pasar yang dimaksudkan adalah memilih pasar yang akan dilayani yang didasari oleh faktor persepsi, keterebatasan sumber daya internal, pengalaman kumulatif dan kemampuan khusus.

\section{METODE PENELITIAN}

\section{Lokasi dan Waktu Penelitian}

Penelitian dilaksanakan secara sengaja (purposive methode) di Kabupaten Bondowoso. Penentuan lokasi penelitian di Kabupaten Bondowoso. Penelitian ini dilaksanakan pada bulan Agustus 2018 dan berakhir pada bulan Oktober 2018.

\section{Metode Pengambilan Sampel}

Populasi merujuk pada sekumpulan orang atau objek yang memiliki kesamaan dalam satu atau beberapa hal yang membentuk masalah dalam penelitian (Santoso dan Tjiptono, 2001:79). Populasi dalam penelitian adalah seluruh konsumen kopi di Bondowoso.

Sampel merupakan bagian atau sejumlah cuplikan tertentu yang diambil dari suatu populasi dan diteliti secara rinci (Santoso dan Tjiptono, 2001:80). Sampel adalah 
bagian suatu obyek yang mewakili populasi. Penelitian ini menggunakan teknik nonprobabilty sampling, yaitu dengan metode purposive sampling. Purposive sampling adalah pemilihan sampel secara cermat dengan menggunakan ciri-ciri atau syarat-syarat tertentu atau spesifik Tika (2006:46). Sehingga syarat sampel penelitian ini antara lain:

1. Konsumen merupakan warga Bondowoso.

2. Konsumen berusia antara 15-65 tahun.

3. Konsumen paling tidak mengkonsumsi kopi dalam dua bulan terakhir.

Sampel dari penelitian ini adalah 150 responden.

\section{Teknik dan Alat perolehan Data}

Data yang digunakan dalam penelitian ini adalah data primer dan data sekunder. Data primer dalam penelitian ini berupa jawaban kuisioner responden dari pertanyaanpertanyaan yang telah dibuat oleh peneliti. Data sekunder dalam penelitian ini berupa informasi relefan dari lembaga yang menjadi obyek penelitian.

Alat perolehan data dalam penelitian ini adalah kuisioner yang dijalankan dengan mempergunakan daftar pertanyaan untuk responden yang tertulis dan tersusun rapi.

\section{Teknik Analisis Data}

Analisis ini bersifat uraian atau penjelasan dengan membuat tabel-tabel, mengelompokkan, menganalisis data berdasarkan pada hasil jawaban kuesioner yang diperoleh dari tanggapan responden dengan menggunakan tabulasi data (Rahayu, 2005:21).

\section{HASIL PENELITIAN}

\section{Segmentasi Demografis}

Segmentasi demografis merupakan upaya mengelompokkan pasar menjadi kelompok konsumen berdasarkan jenis kelsamin, usia, pekerjaan, pendapatan, dan latar belakang pendidikan. Hasil penelitian menunjukkan bahwa $66,67 \%$ dari data responden merupakan konsumen kopi dengan jenis kelamin laki-laki, sedangkan 33,33\% sisanya adalah perempuan.

Hasil penelitian, berdasarkan kategori di atas, tidak menggunakan kategori Balita, Anak-anak dan 66 tahun ke atas karena penelitian ini dimulai dengan usia 15 tahun ke atas sampai usia 65 tahun. Hasil penelitian menunjukkan bahwa kelompok Remaja Akhir 
(usia antara 17 sampai 25 tahun) mendominasi konsumsi kopi olahan di Kabupaten Bondowoso dengan berbagai merek sebesar 39,33\%, disusul oleh kelompok konsumen Dewasa Akhir (usia antara 36 sampai 45 tahun) sebesar 25,33\%, kemudian disusul oleh kelompok Dewasa Awal (usia 26 sampai 35 tahun) 24\%, lalu kelompok Masa Lansia Akhir (usia 56 sampai 65 tahun) sebesar 5,34\%, kemudian kelompok Masa Lansia Awal (usia 46 sampai 55 tahun) sebesar 4\% dan terakhir adalah kelompok Remaja Awal ( usia 12 sampai 16 tahun) yakni sebesar 2\%. Remaja akhir ini merupakan kelompok usia yang mewakili kelompok kaum muda. Hasil penelitian ini mendukung penelitian dari Herlyana (2012) konsumsi kopi berhubungan dengan gaya hidup kaum muda.

Hasil penelitian menunjukkan segmentasi konsumen kopi berdasarkan status pernikahan. bahwa 65,3\% konsumen memiliki memiliki status menikah dan selebihnya $34,67 \%$ berstatus belum menikah. Penelitian ini juga menunjukkan bahwa 49,33\% konsumen kopi di Kabupaten Bondowoso memiliki pekerjaan sebagai wiraswasta, 22\% konsumen kopi merupakan pelajar/mahasiswa, konsumen yang memiliki pekerjaan utama sebagai karyawan swasta sebanyak 10\%, 9,33\% konsumen kopi adalah ibu rumah tangga, 8,68 \% konsumenn bekerja sebagai guru/PNS/POLRI/TNI dan sisanya 0,67\% konsumen kopi adalah tidak bekerja. Penelitian ini juga memperlihatkan bahwa segmentasi konsumen kopi berdasarkan pendapatan paling besar $92 \%$ konsumen kopi memiliki pendapatan kurang dari 2 juta, 5,33\% konsumen kopi memiliki pendapatan sebesar 2 sampai dengan 3 juta, dan sisanya 2,67\% konsumen kopi memiliki pendapatan lebih dari 3 juta. Hasil penelitian ini menunjukkan bahwa sebagian besar konsumen kopi memiliki adalah konsumen yang berada di kelas menengah ke bawah.

Segmentasi konsumen kopi berdasarkan latar belakang pendidikan menunjukkan bahwa konsumen kopi terbesar adalah konsumen kopi yang memiliki latar belakang pendidikan SMA yakni sebesar 69,33\%, 11,33 \% konsumen kopi memiliki latar belakang pendidikan SD, 8,68 \% kopnsumen kopi memiliki pendidikan D3/Sarjana, 7,33\% konsumen kopi memiliki pendidikan SMP dan selebihnya tidak sekolah yakni 3,33\%.

\section{Segmentasi Geografis}

Segmentasi berdasarkan faktor geografis menunjukkan bahwa konsumen kopi yang memiliki tempat tinggal dengan jarak lebih dari $5 \mathrm{Km}$ dari kota menempati posisi teratas yakni 51,34\%, kemudian konsumen kopi yang memiliki jarak tempat tinggal 5 $\mathrm{Km}$ dari kota menempati posisi kedua yakni sebsar 43,33\%, dan konsumen kopi yang 
memiliki tempat tinggal dalam kota menempati posisi terakhir sebesar $\quad 5,33 \%$. Penelitian ini menunjukkan bahwa konsumen kopi yang memiliki tempat tinggal jauh dari kota yakni pedesaan merupakan segmen pasar kopi terbesar di Kabupaten Bonowoso.

\section{Segmentasi Psikografis}

Segmentasi berdasarkan faktor psikografis terdiri dari kelas sosial dan gaya hidup yang teraktualisasi dalam persepsi dan preferensi konsumen. Persepsi dan preferensi konsumen digambarkan melalui pemilihan kopi olahan favorit, pembelian, status penggunaan, status konsumen dengan produk, status loyalitas konsumen, hubungan loyalitas konsumen dan manfaat produk dengan konsumen.

Segmentasi psikografis yang pertama menunjukkan jumlah konsumen kopi yang dikelompokkan berdasarkan kopi olahan favorit konsumen. Segmentasi tersebut menyebutkan bahwa 25,33\% konsumen kopi lebih memilih kopi dengan merek Top Coffee dibanding kopi yang lain. Hal ini karena responden memiliki alasan bahwa kopi Top Coffee memiliki rasa yang enak, nikmat dan beraroma wangi dibanding kopi merek lainnya. Kopi Kapal Api dan Kopi Torabika menempati posisi kedua dengan persentase 23\%, Kopi Olahan Sendiri menempati posisi ketiga dengan persentase 21\%, Nescafe menempati posisi keempat dengan persentase $15 \%$, posisi kelima ditempati kopi dengan merek Indocoffee dengan persentase $7 \%$ dan sisanya ditempati oleh merek kopi lainya (white coffee) sebesar 3\%.

Hasil penelitian ini menunjukkan pola pembelian kopi oleh konsumen. 78,67\% konsumen sering membeli kopi, 14,67\% konsumen kadang-kadang membeli kopi dan sebagian kecil 6,66\% jarang membeli kopi. Hal ini menunjukkan bahwa sebagian besar konsumen kopi di Kabupaten Bondowoso sering membeli kopi.

Penelitian ini juga menunjukkan segmentasi konsumen kopi berdasarkan pola penggunaan kopi. Pola penggunaan kopi terbagi atas pengguna regular, pengguna potensial (jarang membeli kopi) dan mantan pengguna. Hasil penelitian menunjukkan bahwa persentase pengguna regular menempati posisi teratas sebesar $82,67 \%$, pengguna potensial (jarang membeli) menempati posisi kedua sebeasr 16,67\%, dan mantan pengguna menempati posisi terakhir sebesar $0,66 \%$. Hasil penelitian menunjukkan bahwa sebagian besar konsumen kopi adalah penggemar kopi dengan persentase sebesar $81,33 \%$, dan sebagian kecil adalah pecandu, pemerhati dan pembeli pemula dengan 
persentase berturut,turut adalah 9,33\%,6,67\% dan 2,67\%. Hal ini menunjukkan gambaran bahwa kosumen kopi kebanyaka adalah konsumen yang sering membeli kopi dengan pola penggunaan regular (ters-menerus) dan memang penggemar kopi.

Segmentasi konsumen kopi berdasarkan loyalitas konsumen dikelompokkan menjadi konsumen loyal, agak loyal (pernah membeli kopi lain), dan tidak menunjukkan loyalitas kepada merek kopi apapun. Hasil penelitian menunjukkan bahwa sebanyak $87 \%$ konsumen kopi merupakan konsumen kopi yang loyal, 48\% konsumen kopi. Penelitian ini menunjukkan gambaran loyalitas konsumen kopi terhadap produknya secara lebih lanjut. Hasil penelitian menunjukkan bahwa sebesar 71,33\% konsumen kopi memiliki loyalitas terhadap merek kopi tertentu, 22\% konsumen kopi memiliki loyalitas terhadap toko/warung, $1 \%$ consumen kopi memiliki loyalitas terhadap perusahaan, 9\% konsumen kopi memiliki loyalitas terhadap lainnya, seperti cita rasa.

Pengelompokan konsumen kopi berdasarkan manfaat yang diperoleh saat meminum kopi diantaranya adalah manfaat kesehatan. kecantikan, penahan kantuk, penyegar badan, kenikmatan rasa, semangat kerja dan kepala tidak pusing. Hasil penelitian menunjukkan bahwa 39,33\% konsumen mengkonsumsi kopi didasarkan pada manfaat kesehatan. Manfaat kenikmatan rasa mendasari 38,67\% konsumen dalam mengkonsumsi kopi. 12,67\% konsumen meminum kopi untuk penghilang kantuk. 6,66\% konsumen meminum kopi untuk penyegar badan, 1,33\% konsumen meminum kopi agar tidak pusing dan $0,67 \%$ konsumen meminum kopi untuk manfaat kecantikan.

\section{Implikasi Kebijakan}

Penelitian ini bermaksud memberikan masukan untuk Kopi Java Ijen Raung yang di produksi oleh kelompok tani di Kabupaten Bondowoso agar bisa memasarkan produknya dan membantu pemilihan strategi pemasaran kopi yang nantinya bisa bersaing dengan kopi olahan yang telah dikenal di pasaran terutama bagi konsumen kopi di Kabupaten Bondowoso sendiri. Penelitian ini telah melakukan evaluasi terhadap segmensegmen konsumen kopi yang ada di pasar,. Boy Sabarguna (2005), menyatakan bahwa pasar potensial (potential market) adalah konsumen yang mempunyai minat pada tawaran atau penawaran pasar yang telah dirumuskan. Pasar potensial juga diartikan sebagai sekumpulan konsumen yang memiliki minat dalam batas-bata tertentu terhadap penawaran yang disampaikan (Kotler dan Andersen, 1995). 
Hasil penelitian menunjukkan bahwa segmen pasar berdasarkan segmentasi demografis konsumen berjenis kelamin laki-laki dengan usia remaja akhir, berpendapatan kurang dari 2 juta (berada di kelas menengah ke bawah), memiliki pekerjaan utama wiraswasta, berstatus menikah, memiliki latar belakang pendidikan SMA merupakan pasar potensial bagi Kopi Java Ijen Raung untuk dikembangkan.

Segmen pasar kopi berdasarkan segmentasi geografis menunjukkan bahwa konsumen yang memiliki tempat tingggal lebih dari $5 \mathrm{Km}$ menempati posisi teratas. Hal ini berarti bahwa banyak konsumen kopi yang berada di desa. Segmentasi berdasarkan faktor psikografis didapatkan bahwa konsumen kopi yang paling banyak adalah penggemar kopi, merupakan konsumen yang loyal, dan loyal terhadap merek kopi menempati posisi teratas. Hal ini berarti segmen pasar potensial kopi di Kabupaten Bondowoso adalah konsumen yang jauh dari kota (desa), merupakan penggemar kopi dan merupakan konsumen yang loyal terhadap merek. Hasil penelitian ini menunjukkan bahwa Kopi Java Ijen Raung harus dapat memperebutkan segmen pasar tersebut dan mempergunakan sumberdayanya untuk meluncurkan strategi pemasaran yang jitu dalam memperebutkan segmen pasar ini.

Tahapan selanjutnya dari penelitian ini adalah menentukan target pasar (targetting). Evaluasi terhadap segmen-segmen yang ada memperhatikan ukuran, pertumbuhan segmen, daya tarik segmen serta sasaran segmen dan sumber daya yang dimiliki oleh perusahaan. Penentuan target pasar dimulai dengan menganalisis segmen yang paling sesuai dan memenuhi kriteria segmentasi pasar yang efektif yaitu: harus dapat diukur (measurable), jumlahnya cukup besar (subtantial), dapat dijangkau (accesible), dapat dibedakan (differentiable), dan dapat dilaksanakan (actionable). Target utama dari penelitian ini sudah dapat terlihat dari hasil penelitian yakni konsumen kopi berjenis kelamin laki-laki dan merupakan konsumen dari kalangan anak muda yakni remaja akhir

Positioning atau penentuan posisi yaitu nilai lebih yang dimiliki Kopi Java Ijen Raung relatif dibanding dengan pesaing yang tertanam di benak pelanggan. Pada bagian terakhir dari semua tahap penelitian ini adalah menentukan posisi Kopi Java Ijen Raung dengan cara melihat produk maka disepakati pemilihan pola spesialisasi selektif (Selective Specialization). Pemilihan pola ini dengan pertimbangan tujuan yang ingin dicapai dan sumber daya yang dimiliki oleh Kopi Java Ijen Raung. Setelah melihat hasil 
posisi Kopi Java Ijen Raung yang dibandingkan dengan kopi olahan lain yang ada di pasaran kopi Java Ijen raung hendaknya melakukan strategi pemasaran melalui strategi pemasaran bauran pemasaran 7P (product, price, place, promotion, poeple, physical evidence, dan process).

\section{KESIMPULAN DAN SARAN}

\section{Kesimpulan}

Hasil Analisa Penelitian ini menunjukkan bahwa:

1. Segmentasi Konsumen kopi berdasarkan faktor demografis menunjukkan bahwa konsumen kopi paling banyak pada kelompok konsumen kopi laki-laki, remaja akhir, berpendapatan kurang dari 2 juta (kelas menengah ke bawah), memiliki pekerjaan utama wiraswasta, menikah dan memiliki latar belakang pendidikan SMA.

2. Segmentasi konsumen kopi berdasarkan faktor geografis menunjukkan konsumen terbanyak berada pada kelompok konsumen yang memiliki tempat tinggal lebih dari 5 $\mathrm{km}$ dari kota (pedesaan).

3. Segmentasi psikografis menunjukkan bahwa konsumen kopi paling banyak memilih Top Coffee sebagai kopi favoritnya dibanding kopi olahan yang lain selain itu kelopok konsumen kopi paling banyak adalah kelompok penggemar kopi yang memiliki loyalitas terhadap merek kopi tertentu.

\section{Saran}

Kopi Java Ijen Raung sebaiknya melakukan strategi pemasaran targetting dengan membidik segmen pasar laki-laki dan remaja akhir dalam pemasarannya, selanjutnya membuat produk yang dapat diterima oleh konsumen yang berada di kelas mengeah ke bawah, berprofesi wiraswasta, memiliki latar belakang pendidikan SMA, diterima oleh konsumen dengan jarak tempat tinggal lebih dari $5 \mathrm{Km}$ dari kota (pelosok desa), dan diterima oleh penggemar kopi meskipun loyal terhadap merek kopi tertentu. 


\section{DAFTAR PUSTAKA}

Arikunto, S. 2006. Prosedur Penlitian: Suatu Pendekatan Praktik. Jakarta: Rineka Cipta.

Kotler, P dan Keller, K.L. 2008. Manajemen Pemasaran. Jilid 1. Jakarta: Erlangga.

Kusdianto, N. 2015. Efisiensi dan Strategi Pemasaran Kopi Arabika (Coffea Arabica) Java Ijen Raung Di desa Sukorejo Kecamatan Sumberwringin Kabupaten Bondowoso. Skripsi. Jember: Fakultas Pertanian Universitas Jember.

Nitisusastro, M. 2013. Perilaku Konsumen Dalam Perspektif Kewirausahaan. Bandung: Alfabeta.

Peter, J.P dan Olson J.C. 2014. Perilaku Konsumen dan Strategi Pemasaran. Buku 1. Jakarta: Salemba Empat.

Peter, J.P dan Olson J.C. 2014. Perilaku Konsumen dan Strategi Pemasaran. Buku 2. Jakarta: Salemba Empat.

Primadani, T. 2012. Analisa Perilaku Konsumen Kopi Di kabupaten Jember Serta Implikasinya Terhadap Staretegi Pengembangan Agroindustri Kopi Bubuk Lokal. Skripsi. Jember: Fakultas Pertanian Universitas Jember.

Sangadji, E.M dan Sopiah. 2013. Perilaku Konsumen Pendekatan Praktis. Yogyakarta: Andi.

Santoso dan Tjiptono. 2001. Riset Pemasaran: Konsep dan aplikasi dengan SPSS. Jakarta: PT Elex Media Komputindo.

Tjiptono, F. 2008. Strategi Pemasaran. Yogyakarta: Andi.

Utami, R.W. 2009. Segmentasi Dan Analisis Perilaku Konsumen Kopi Bubuk. Jurnal JSEP, 3(2): 49-58. 